\title{
Effects of storage conditions and pre-chilling periods on germinability of Pinus ponderosa seeds from Patagonia, Argentina: preliminary study
}

\author{
Efectos de las condiciones de almacenamiento y de la estratificación sobre la germinación de \\ semillas de pino ponderosa de Patagonia, Argentina: estudio preliminar
}

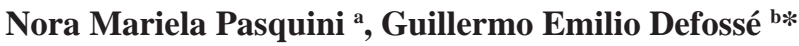 \\ ${ }^{a}$ Universidad Nacional de la Patagonia and Centro de Investigación y Extensión Forestal Andino Patagónico (CIEFAP), \\ Seeds Laboratory, Ruta 259 km 4, (9200) Esquel, Chubut, Argentina, mpasquini@ciefap.org.ar

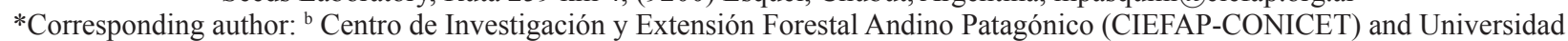 \\ Nacional de la Patagonia, Ruta 259 km 4, (9200) Esquel, Chubut, Argentina, phone: 54-2945 453948,
}

fax: 54-2945 450175, gdefosse@ciefap.org.ar

\begin{abstract}
SUMMARY
In Argentinean Patagonia, ponderosa pine seeds (Pinus ponderosa) are collected in good production years, stored at ambient conditions, and used thereafter for seedling production. However, information about the effects of conditions and periods of storage on seed quality is scarce. The objectives of this study were: a) to evaluate germination percentage (GP) and germination energy (GE), of ponderosa pine seeds recently collected, and after three and four years of storage in plastic boxes at ambient conditions, and b) to determine if different pre-chilling periods might influence GP and GE as a function of storage time. Part of a seed lot, collected in 2000 in a mesic site near the town of Trevelin in Patagonia, was used to determine moisture content, GP and GE (using 21-days prechilling). Another part of that seed lot, stored at ambient conditions for three and four years, was subjected to pre-chilling for 21, 40 and 60 days. Following 21-days pre-chilling, GE was $34 \%$ and $14 \%$ after three and four years of storage, respectively. Pre-chilling periods of 40 and 60 days increased GE to $62 \%$ and $59 \%$ for seeds stored for three and four years, respectively. GP was maintained at ca $69 \%$ over the four years of storage with a seed moisture content of $7 \%$. Patagonian nurseries could store their own harvested seed under the conditions established in this study without significant loss of seed viability
\end{abstract}

Key words: Pinus ponderosa, pre-chilling, seed storage, viability.

\section{RESUMEN}

En Patagonia, Argentina, semillas de pino ponderosa (Pinus ponderosa) cosechadas en años de buena producción, son almacenadas a temperatura ambiente y luego, usadas para producir plantas. Sin embargo, la información sobre las condiciones y períodos de almacenamiento en la calidad de la semilla es escasa. Los objetivos de este estudio fueron: a) determinar los porcentajes de germinación (PG) y energía germinativa (EG), de semillas recientemente cosechadas y luego de ser almacenadas a temperatura ambiente en recipientes plásticos cerrados por tres y cuatro años; y b) determinar si diferentes períodos de estratificación frío-húmeda influencian su EG y PG con el tiempo de almacenamiento. A parte de un lote de semilla, cosechado el año 2000 en Trevelin ( $43^{\circ} 04^{\prime} 44^{\prime \prime}$ S, $71^{\circ} 27^{\prime}$ $54^{\prime}$ O), se le determinó su contenido de humedad, EG y PG usando 21 días de estratificación. Otra parte fue almacenada en condiciones ambientales por tres y cuatro años. Al cabo de este tiempo, se determinó su PG y EG estratificando la semilla por 21,40 y 60 días. Con 21 días, la EG fue $34 \%$ y $14 \%$ después de tres y cuatro años, respectivamente; la estratificación por 40 y 60 días incrementó la EG al $62 \%$ y $59 \%$ en los mismos períodos. Después de cuatro años de almacenamiento, las semillas mantuvieron el contenido de humedad en 7 \%, y el PG en 69 \%. Los viveros de Patagonia podrían almacenar sus semillas bajo las condiciones citadas sin pérdidas de viabilidad por cortos períodos de tiempo.

Palabras clave: Pinus ponderosa, período de estratificación, almacenamiento de semillas, viabilidad.

\section{INTRODUCTION}

For many forest trees, fruit bearing may vary yearly, and high seed production years are followed by others with low or zero production. Seed harvesting in good production years could offer the advantages to choose seeds from phenotypically superior trees; seeds that may have higher germination capacity and longer viability periods than those harvested in low production years (Hilli et al.
2003, Sharma et al. 2004, Malik and Shamet 2009). In native ponderosa pine (Pinus ponderosa Dougl. ex. Laws) forests of North America, the interval between good seed harvest years could vary from two to five (Wenny and Dumroese 1987, USDA Forest Service 1989). In Patagonia, this species shows good seed production years followed by two to four poor production years ${ }^{1}$. Since the area being planted with this species is constantly increa-

\footnotetext{
${ }^{1}$ NM Pasquini: unpublished data.
} 
sing, Patagonian nurseries have difficulty procuring sufficient seed (both in quantity and quality) to satisfy demand. Therefore, it is necessary to take advantage of good seed production years and store the excess seeds for later use when seed production is low.

In general, the goal of seed storage is to conserve seeds in a way that maintains their viability and vigor for the longest possible time from harvest to sowing (Hilli et al. 2003, Rajjou and Debeaujon 2008). Although seed longevity is an intrinsic characteristic that varies from species to species (Walters et al. 2005), the period during which seeds remain viable will depend on their quality at the time of harvest, the treatment received between collection and storage, and the storage conditions (Walters 2007, Rajjou and Debeaujon 2008). In addition, seeds of most conifers also require a further treatment to break physiological dormancy to enhance germination. This dormancy can be removed through cold-moist stratification (pre-chilling), consisting in incubating imbibed seeds in a moist medium at 1 to $5^{\circ} \mathrm{C}$ for periods varying from a week up to several months (Bradbeer 1992, Jones and Gosling 1994). For ponderosa pine seeds however, there is conflicting information concerning the optimum pre-chilling periods required to break dormancy (AOSA 1984, ISTA 1993, 1999, 2003). In Patagonia, there is some evidence (Pasquini et al. 2008) that for seeds stored for three years, the optimum stratification period for maximizing germination energy went beyond the 21 days suggested by ISTA (1993).

In relation to their behavior during storage, ponderosa pine seeds belong to the "orthodox" category, since they have shown no loss of viability after seven years of storage at $0{ }^{\circ} \mathrm{C}$, with $8 \%$ of seed moisture content (Bonner et al. 1994). Related to storage conditions, moisture content and storage temperature appear to be the most important factors that influence further seed quality (i.e. viability and vigor) (Walters et al. 2005, Walters 2007, Rajjou and Debeaujon 2008). Although storage at ambient temperatures may affect longevity, seeds of most species can be held at cold temperatures $\left(0-4{ }^{\circ} \mathrm{C}\right)$ for long periods with little impact on viability. However, refrigeration storage is expensive, and may be unnecessary for short periods of storage. Considering also that the range of temperatures used to store orthodox seeds is mostly related to their moisture content (Walters 2007), seeds may be conserved safely at temperatures over $4{ }^{\circ} \mathrm{C}$ if their moisture content is from 5 to $10 \%$ (Bonner et al. 1994). Seed moisture content can be controlled by retaining seeds in sealed containers, or regulating the relative humidity in the store. In Patagonia, most nurseries store ponderosa pine seeds for several years under ambient (uncontrolled) temperatures in a variety of container types. Although they may take advantage of the relatively cool and dry conditions of this region, specific storage conditions related to temperature and relative humidity vary among nurseries. Potential seed germination energy and germination percentage of different seed lots of ponderosa pine in Patagonia are then highly variable, given the wide range of storage conditions used. Furthermore, little is known about optimum pre-chilling periods required to maximize germination energy and germination percentage values of ponderosa pine seeds following several years of storage.

The two objectives of this study were: a) to evaluate changes in moisture content, germination percentage, germination energy, on ponderosa pine seeds either fresh or after three and four years of storage in plastic boxes at room temperature, and $b$ ) to determine if the duration of different pre-chilling periods (21, 40, and 60 days) might affect germination energy and germination percentage following different periods of storage. The ultimate aim of this study was to provide practical information about the pre-chilling periods to be used and the best way of storing ponderosa pine seeds.

\section{METHODS}

Seed collection and germination analyses. Seeds used came from ponderosa pine cones harvested in 2000 from stands located near the town of Trevelin, Chubut, in Patagonia, Argentina ( $43^{\circ} 04^{\prime} \mathrm{S}, 71^{\circ} 27^{\prime} \mathrm{W}$, at $400 \mathrm{~m}$ a.s.1.). The collection area has a Mediterranean climate; mean annual precipitation and temperature are 1,028 $\mathrm{mm}$ and $9.7{ }^{\circ} \mathrm{C}$, respectively (INTA Research Station, Trevelin). After collection, the cones were placed in trays and exposed to full sun for drying. After a week, trays were piled in a heated room (at $35-45^{\circ} \mathrm{C}$ ) to allow further cone opening. Open cones containing the seed were put in a rotary tumbler. Seeds were then dewinged, and finally cleaned by air screen cleaner equipment (MAZ) to remove inert matter and other small debris. This procedure gave a seed lot purity of $99.9 \%$, following standard operational practices in Patagonia. Some seeds were used immediately, while the remainder were placed in plastic boxes (Tupperware type) containing about $2 \mathrm{~kg}$ of seeds each, and stored in a room at ambient conditions. These conditions were: $16 \pm 2{ }^{\circ} \mathrm{C}$ and 40 to $50 \%$ relative humidity during summertime and $7 \pm 2{ }^{\circ} \mathrm{C}$ and 50 to $60 \%$ relative humidity during wintertime, respectively. Seed moisture content (based on fresh weight) was determined by oven-drying seed samples (at $103{ }^{\circ} \mathrm{C}$ during $17 \pm 1$ hour, ISTA 1999) right after collection (year 2000), repeating it after three (2003) and four (2004) years of storage.

Seeds were subjected to standard germination tests to determine germination energy and germination percentage (ISTA 1993), both before and after storage. Germination energy and germination percentage were defined as the percentage of seeds germinated at 7 and 21 days after sowing, respectively (Pasquini et al. 2008). Briefly, the germination test consisted in soaking seeds for $24 \mathrm{~h}$ (to reach $30 \%$ moisture content), drained and pre-chilled for 21 days at $3-5{ }^{\circ} \mathrm{C}$. After pre-chilling, four 50 -seed replications per treatment were placed in $(26 \mathrm{~cm} * 18 \mathrm{~cm})$ 
plastic boxes containing sterilized sand (moistened with distilled water). The boxes were exposed daily to 8 hours at $25^{\circ} \mathrm{C}$ and 1,250 lux (measured with an Extech Light Meter, Model SE 9087) and 16 hours dark $\left(20^{\circ} \mathrm{C}\right)$, for 21 days. Germination temperatures were chosen based on previous experiences, which indicate that ponderosa pine seeds germinate better when stored between 20 to $25^{\circ} \mathrm{C}$ (Weber and Sorensen 1990). Seeds were considered germinated when all seedling structures were visible, allowing their classification as normal or abnormal seedlings. Non-germinated seeds were classified as dead of vane. In February 2003 and February 2004, moisture content, germination energy and germination percentage were determined for the seeds that had been stored at room conditions since 2000, following chilling for 21, 40 and 60 days.

Experimental design and statistical analyses. Data were analyzed by an ANOVA using the InfoStat Statistical Package (InfoStat 2002), to test for the effects of storage duration (following 21-day chilling) and chilling duration (stored seeds only) on the germination percentage and germination energy responses (after arcsin $\sqrt{ } \% \mathrm{PG} / 100$ transformation). The Duncan test was used to separate means further.

\section{RESULTS}

Seed moisture content. At the beginning of the storage, seed moisture content of ponderosa pine seeds collected in Patagonia was around $7 \%$, and remained unchanged during storage until 2003 and 2004.

Germination percentage and germination energy. Germination percentage remained almost constant at around $65 \%$ from the beginning of storage in 2000 until the end of storage in 2004 (figure 1A). Increasing prechilling, from 21 days in 2000 to 40 or 60 days in 2003 and 2004, did not significantly increase germination percentage. For seeds pre-treated for 21 days, germination energy, by contrast, did not differ significantly from the pre-storage values during the first three years of storage, remaining at around 35-40\%. Germination energy, however, declined significantly $(P<0.05)$ by the fourth year, reaching around $14 \%$ (figure $1 \mathrm{~B}$ ).

Effects of increasing pre-chilling periods on germination percentage and germination energy of stored seeds. Germination percentage slightly increased three years after storage when prechilling periods were extended from 21 to 40 and from 40 to 60 days (figure 1A). After four years of storage, germination percentage appeared to have reached its maximum with 40-day prechilling, and the extension of this pre-treatment to 60 days did not increase germination percentage values (figure 1A). On the other hand, pre-chilling periods of 40 and 60 days increased germination energy compared with the standard 21-day chilling
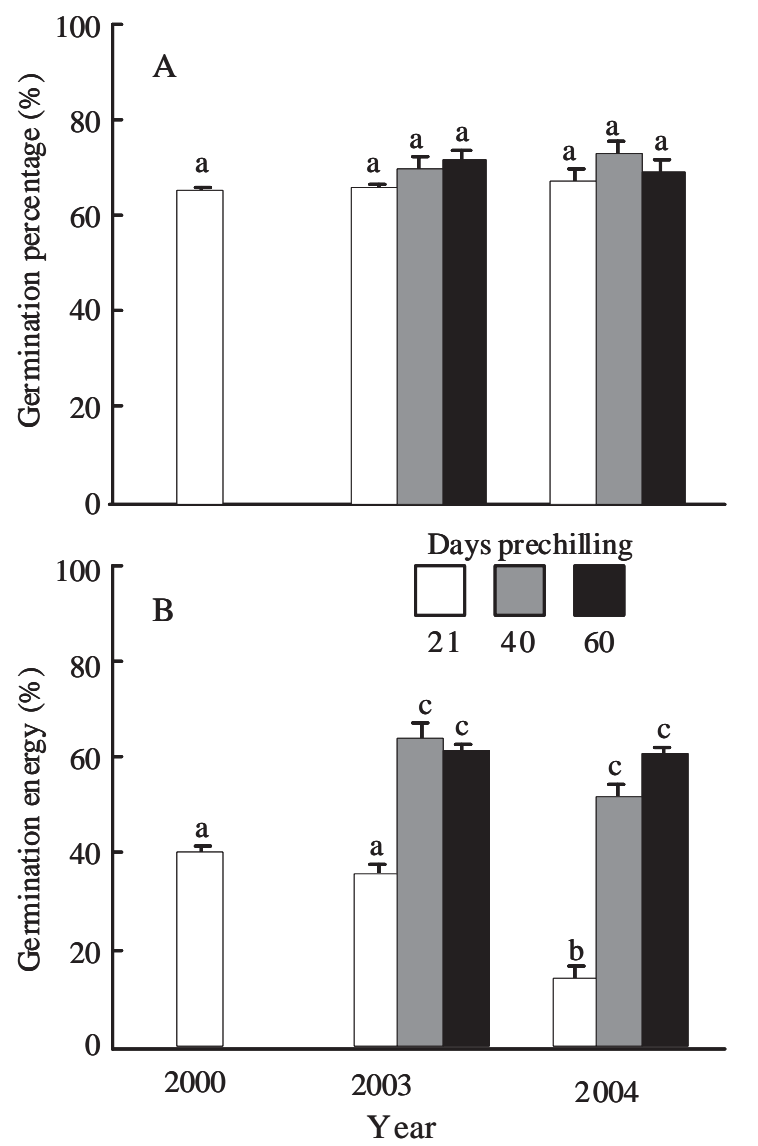

Figure 1. A) Germination percentage (GP) and B) germination energy (GE) of ponderosa pine seeds collected in Patagonia, Argentina, subjected to different pre-chilling periods after three and four years of storage in plastic boxes at ambient conditions (grey and black bars, respectively). Different lower case letters indicate significant differences $(P<0.05)$ in GE or GP.

A) Porcentaje de germinación (GP), y B) energía germinativa (GE) de semillas de pino ponderosa cosechadas en Patagonia, Argentina, sujetas a diferentes períodos de estratificación frío-húmeda luego de tres (2003) y cuatro (2004) años de almacenamiento en cajas plásticas a temperatura ambiente (barras grises y negras, respectivamente). Diferentes letras minúsculas muestran diferencias significativas $(P<0,05)$ en GP o GE, respectivamente.

recommended by ISTA (1993) for seeds stored for three or four years (figure 1B). Furthermore, in seeds stored for four years, germination energy also significantly increased when pre-chilling period was extended from 40 to 60 days. For seeds chilled for only 21 days, there was a statistically significant decline in germination energy from the third to the fourth year of storage (figure 1B).

\section{DISCUSSION AND CONCLUSIONS}

Seed moisture content and storage temperature are considered the main determinants of seed longevity, at least for orthodox seeds (Walters et al. 2005, Walters 2007). This category of seeds, to which ponderosa pine 
belongs, can be preserved for many years by ensuring that their moisture content is below certain threshold values during storage at low temperatures (Bonner et al. 1994). However, the mechanisms involved in this process (i.e. interactions between temperature and water content) are not yet completely understood (Walters 2007, Rajjou and Debeaujon 2008). In our work, and although we have not studied such interactions, it seems that the maintenance of ponderosa pine seed moisture content around $7 \%$ and ambient temperatures (from $7{ }^{\circ} \mathrm{C}$ to $16{ }^{\circ} \mathrm{C} \pm 2{ }^{\circ} \mathrm{C}$ during winter and summertime, respectively) in sealed plastic containers, do not have any detrimental effects on seed viability. The plastic sealed containers used in this study allowed maintaining seed moisture content without modifications throughout all the storage period.

Related to germination percentage, and for seeds stored for four years at ambient conditions (with $7 \%$ seed moisture content), 40-day prechilling produced the maximum values in this parameter, and an extension of this period to 60 days did not produce any additional increment. Furthermore, the extension of prechilling beyond this period is unpractical, being more appropriate to practice autumn sowing. On the other hand, 21-day pre-chilling treatment recommended by ISTA (1993) seemed insufficient to maintain the germination energy values obtained at the beginning of the experiment (year 2000, fresh seeds) as compared to the subsequent values determined in 2003 and 2004. With this pre-chilling treatment and after three years of ambient storage, ponderosa pine seeds start to rapidly lose their germination energy. In agreement with this observation, Roos (1980) reported that seed vigor (i.e. germination energy) declined during storage. To revert this, longer pre-chilling periods (to 40 and 60 days, respectively) for stored seeds may be needed to improve germination energy as compared to the standard 21-day pre-chilling (Krugman and Jenkinson 1989, Wang and Pitel 1991). Germination energy is known to be dependent on genetic control that may vary among seedlots (ElKassaby and Namkoong 1996, El-Kassaby and Edwards 1998, Hilli et al. 2003); hence, there may be considerable variability in the response to pre-chilling both among and within pine species.

It is suggested that for seeds collected in other regions of Patagonia with similar environmental conditions to those prevailing in our study area (mesic location, Mediterranean climate with rains concentrated during winter and spring), pre-chilling periods should be extended for at least 40 to 60 days prior to sowing. Optimal times of pre-chilling and storage may be necessary to be determined and adjusted for provenances coming from other areas with markedly different environmental conditions.

In summary, ponderosa pine seeds harvested in a mesic environment of Patagonia, stored at ambient conditions in sealed plastic containers, remain viable for at least four years after collection. It is important to mention, however, that for achieving this, seed moisture content should remain around $7 \%$. The beneficial effects of longer prechilling periods on germination energy (as compared to the traditional 21 days) were evident for seeds stored at ambient conditions for up to four years, allowing to increase their germination energy about twice and four times more as compared to the standard 21-day pre-chilling. The increase obtained in germination energy values by extending their pre-chilling period is important for maintaining seed vigor over longer periods of storage, since good seed years are infrequent. This aspect is particularly valuable for $\mathrm{Pa}-$ tagonian nursery owners, who still harvest, condition, and use their own seeds in seedling production programs.

\section{ACKNOWLEDGEMENTS}

This study was supported by a grant from Proyecto Forestal de Desarrollo (SAGPyA-BIRF PIA 05/01) of Argentina.

\section{REFERENCES}

AOSA (Association of Official Seed Analysts). 1981-1984. Rules for testing seeds. Journal of Seed Technology 6: 1-124.

Bonner FT, JA Vozzo, WW Elam, SB Land (Jr). 1994. Tree seed technology training course. Instructor's manual. USDA Forest Service, Southern Forest Experiment Station General Technical Report SO-106. New Orleans, LA, USA. 160 p.

Bradbeer JW. 1988. Seed dormancy and germination. Blackie and Son Ltd. Glasgow. UK. 146 p.

El-Kassaby YA, G Namkoong. 1996. Genetic diversity of forest tree plantations: Consequences of domestication. In Proceedings of the IUFRO XX World Congress: Caring for Forests: Research in a Changing World. Gummerus, Jyäskilä, Finland. p. 218-228.

El-Kassaby YA, DGW Edwards. 1998. Genetic control of germination and the effects of accelerated aging in mountain hemlock seeds and its relevance to gene conservation. Forest Ecology and Management 112: 203-211.

Hilli A, E Tillman-Sutela, A Kauppi. 2003. Germination of pretreated Scots pine seeds after long-term storage. Canadian Journal of Forest Research 33: 47-53.

InfoStat. 2002. Infostat/Estudiantil, versión 2.0. Grupo Infostat FCA. Universidad Nacional de Córdoba. Ed. Brujas. Córdoba, Argentina.

ISTA (International Seed Testing Association). 1993; 1996; 1999; 2003. International Rules for Seed Testing. Seed Science and Technology, Supplements 21, 24, 27 and 31.

Jones SK, PG Gosling. 1994. "Target moisture content" prechill overcomes the dormancy of temperate conifer seeds. New Forests 4: 309-321.

Krugman SL, JL Jenkinson. 1989. Pinus L. In Seed of Woody Plants in the United States. Washington, D.C. USA. p. 598638. (USDA Handbook 450).

Malik AR, GS Shamet. 2009. Storage of Pinus gerardiana seeds: biochemical changes and its applicability as vigour test. Research Journal of Seed Science 2: 48-55.

Pasquini NM, GE Defossé, O Del Longo. 2008. Upgrading germinability of ponderosa pine seeds From Patagonia, 
Argentina, by adjusting prechilling periods and applying the IDS technique. New Forests 36: 93-102.

Rajjou L, I Debeaujon. 2008. Seed longevity: Survival and maintenance of high germination ability of dry seeds. Comptes Rendues Biologies 331: 796-805.

Ross, EE 1980. Physiological, biochemical and genetics changes in seed quality during storage. HortScience 15: 781-84.

Sharma S, PS Neggi, TS Thakur, S Kumar. 2004. Study on germination and longevity in seeds of Hippophae tibetana. Indian Forester 130: 126-133.

USDA Forest Service. 1989. Seeds of woody plants in the United States. Washington D.C. USA. 883 p. (Agriculture Handbook $\mathrm{N}^{\mathrm{o}}$ 450).

Walters C. 2007. About the limited benefit of water content and temperature on orthodox seed longevity. South African
Journal of Botany 73: 495-496.

Walters C, LM Wheeler, JM Grotenhuis. 2005. Longevity of seeds stored in a genebank: species characteristics. Seed Science Research 15: 1-20.

Wang BSP, JA Pitel 1991. Germination of dormant tree and shrub seeds. In Tree and Shrub Seed Handbook. ISTA. Zurich, Switzerland p. 6-1/6-16.

Weber JC, FC Sorensen. 1990. Effects of stratification and temperature on seed germination speed and uniformity in central Oregon ponderosa pine (Pinus ponderosa Dougl. Ex Laws.). USDA For. Ser. Res. Pap. PNW-RP-429. 13 p.

Wenny DL, RK Dumroese. 1987. A growing regime for containerized Ponderosa pine seedlings. Moscow, ID, USA. University of Idaho, Idaho Forest, Wildlife and Range Experiment Station. 9 p. (Bulletin 43). 
